\title{
Patrimônio, paisagem e simbolismos no centro histórico de Aquiraz, Ceará, Brasil
}

\author{
Yan de Abreu Gomes Vasconcelos 1
}

\begin{abstract}
Resumo: A pesquisa objetivou analisar a dimensão subjetiva estabelecida a partir dos diversos olhares dos moradores da cidade de Aquiraz, Ceará, sobre sua paisagem patrimonial. Metodologicamente, optamos pela prática da observação participante e realização de entrevistas de caráter semiestruturado, pois a mesma ofereceu melhor embasamento na leitura dos significados presentes na paisagem simbólica da área de estudo. Após a realização dos diálogos com os residentes de Aquiraz e a análise de suas falas, identificamos que os aquirazenses nutrem e mantém pelo núcleo inicial de sua cidade um sentimento de vínculo com o lugar. Os residentes entendem que aquele espaço simboliza o início de sua cultura e de sua identidade, um elo que os liga pela nostalgia, memória e pertencimento ao lugar.

Palavras-chave: Paisagem cultural; patrimônio cultural; formas simbólicas espaciais; percepção urbana; significados urbanos.
\end{abstract}

\section{Patrimonio, paisaje y simbolismo en el centro histórico de Aquiraz, Ceará, Brasil}

Resumen: La investigación tuvo el objetivo de analizar la dimensión subjetiva desde diversos puntos de vista de los habitantes da la ciudad de Aquiraz, Ceará, sobre su paisaje patrimonial. Metodológicamente, elegimos la opción de practicar la observación participativa y realización de entrevistas de carácter semiestructurado, pues la mismo ofreció mejores resultados en la lectura de los significados presentes en el paisaje simbólico del área de estudio. Después de dialogar con los residentes de Aquiraz e analizar sus afirmaciones, se pudo identificar el apego por el núcleo inicial de su ciudad, un sentimiento de pertenencia al lugar. Los habitantes entienden que tal espacio simboliza el inicio de su cultura e identidad. Una relación que los une por la nostalgia, la memoria y la pertenencia.

Palabras-clave: Paisaje cultural, patrimonio cultural, formas simbólicas espaciales, percepción urbana, significados urbanos.

\section{Heritage, landscape and symbolism in the historic center of Aquiraz, Ceará, Brazil}

Abstract: The research aimed to analyze the subjective dimension established from the different views of the inhabitants of the city of Aquiraz, Ceará, about its heritage landscape. Methodologically, we opted for the practice of participant observation and conducting semi-structured interviews, as it offered better support to read the meanings present in the symbolic landscape of the study area. After conducting the dialogues with the residents of Aquiraz, and analyzing their statements, it has been identified that the inhabitants maintain an attachment with the place through the initial nucleus of their city. Residents understand that that space symbolizes the beginning of their culture and identity, a bond that links them through nostalgia, memory, and belonging to the place.

Keywords: Cultural landscape; cultural heritage; spatial symbolic forms; urban perception; urban meanings.

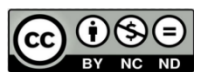

DOI: https://doi.org/10.26512/patryter.v4i8.31786

Como citar este artigo: Vasconcelos, Y. A. G. (2021). Patrimônio, paisagem e simbolismos no centro histórico de Aquiraz, Ceará, Brasil. PatryTer - Revista Latinoamericana e Caribenha de Geografia e Humanidades, 4(8), 123-141. DOI: https://doi.org/10.26512/patryter.v4i8.31786

Recebido: 26 de maio de 2020. Aceite: 12 de fevereiro de 2021. Publicado: 01 de setembro de 2021.

${ }^{1}$ Geógrafo e Mestre pela Universidade Estadual do Ceará - UECE. ORCID: https://orcid.org/0000-0002-95250816.E-mail: yancdz@gmail.com. 


\section{Introdução}

Nas últimas décadas, observamos no Brasil um intenso movimento de recuperação, preservação e proteção de bens e conjuntos patrimoniais de toda a ordem, uma ação que não se restringe apenas às capitais estaduais ou grandes cidades, mas, sobretudo, é notório um aumento na preocupação com a conservação destes importantes objetos de memória nas médias e pequenas cidades, que entendem os seus acervos históricos como uma possibilidade de extrair lucros e renda, especialmente no que tange as atividades turísticas, além de um meio de manutenção e preservação da memória e identidade cultural da sociedade para as gerações futuras.

Tal movimento foi influenciado, sobremaneira, pelas pesquisas e estudos realizados no seio das universidades, pelas mais diversas ciências sociais como a História, a Sociologia, a Antropologia e a Geografia, que compreenderam o patrimônio cultural enquanto considerável meio para se entender as práticas humanas e sociais. Neste contexto, lançar o olhar geográfico sobre o patrimônio cultural é encarar diferentes nuances de um fenômeno humano e social que se concretiza no lugar.

O olhar geográfico não é singular ou estático. Há aqueles(las) geógrafos(as) que se põem a observar determinado monumento, palácio ou templo e o concebe enquanto uma peça importante na trama das atividades turísticas que aquece a economia de uma cidade ou município (Mesquita, 2020; Espoz \& Fernández, 2020). Há aqueles(las) que observam essas formas e as leem como objetos espaciais que registram as condições sociais, as técnicas e o sistema de produção existentes em um específico recorte temporal, se perpetuando na paisagem (Oliveira, 2020; Cardoso e Albuquerque, 2020). Tais formas do passado, que perduram no presente, são nomeadas de "rugosidades" por Santos (2012).

Mas, também, existem estudiosos(as) que analisam o patrimônio cultural e a paisagem para além de sua face material, buscando compreender a dimensão imaterial ou simbólica que estão presentes nestes objetos do passado (Corrêa, 2007; Costa, 2003). Dimensão essa que é permeada por símbolos e significados, percepções, representações, profundos laços afetivos que são construídos entre aqueles que vivenciam o espaço e as formas presentes na paisagem. Para estes geógrafos, notadamente os que seguem uma linha de análise guiada pelo viés cultural, o patrimônio é entendido enquanto uma forma simbólica espacial (Corrêa, 2007) ou, ainda, enquanto um geossímbolo (Bonnemaison, 2012) presente em uma paisagem cultural. É nesta perspectiva teórica que a esta pesquisa foi desenvolvia.

Desta maneira, este artigo tem como objetivo identificar e analisar a dimensão subjetiva estabelecida a partir dos diversos olhares dos moradores sobre a paisagem cultural do centro histórico da cidade de Aquiraz - CE; uma pequena cidade localizada na região metropolitana de Fortaleza, Brasil (fig. 1), que apesar de já não possuir o mesmo significado político e importância econômica de outrora, conserva em seu acervo patrimonial muito da história e estética arquitetônica do período colonial cearense. Abordaremos melhor o tema no desenrolar do texto.

Metodologicamente, em concordância com nossas escolhas teóricas, optamos por nos debruçar, especialmente, sobre os relatos e percepções extraídos dos discursos dos moradores da cidade, em relação às vivências e experiências do sujeito no centro histórico e com seu acervo arquitetônico. Para tanto, elegemos o uso de uma metodologia qualitativa, por esta se voltar a questões subjetivas e simbólicas, um nível de realidade que não pode ser mensurado através de dados objetivos, de equações e estatísticas. No que tange as técnicas utilizadas, optamos pela prática da observação participante e realização de entrevistas, pois as mesmas nos dariam melhor embasamento e subsídios na leitura dos significados presentes na paisagem simbólica da nossa área de estudo.

No que diz respeito a entrevista, optamos pela utilização de um roteiro de perguntas semiestruturado. Nesta modalidade de entrevista, é preestabelecido um itinerário de questionamentos cuja função era nos guiar para a obtenção dos melhores resultados, reservando o direito de não nos prendermos ao plano de perguntas e pudermos realizar novas perguntas durante a entrevista.

Posto isso, o presente artigo foi estruturado em quatro momentos. Iniciamos apresentando o lócus de nossa investigação, o centro histórico da cidade de Aquiraz, pontuando alguns acontecimentos históricos que tornam aquele espaço tão significativo para a história e cultura do estado do Ceará. Em seguida, traremos uma breve exposição da fundamentação teórica que nos guiou durante o desenvolvimento da pesquisa, centrando especialmente na discussão dos conceitos de paisagem cultural e forma simbólica espacial. 
Figura 1 - Mapa de localização da cidade de Aquiraz - CE

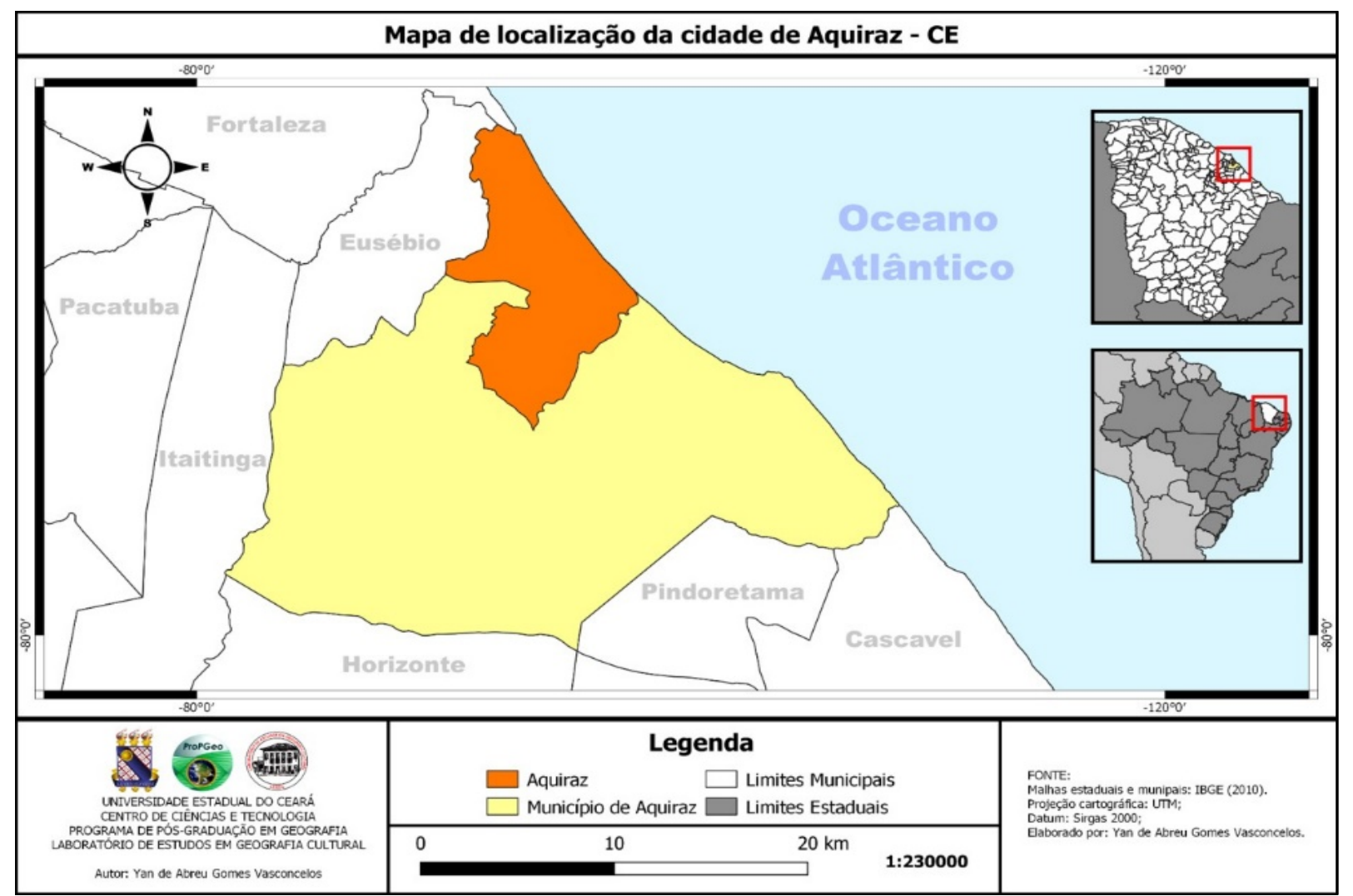

Fonte: elaboração própria, 2019.

O terceiro momento do artigo se reserva à melhor exposição da metodologia e das técnicas de pesquisa utilizadas. Por fim, encerraremos o artigo analisando a dimensão simbólica formada pelos diversos significados, memórias e laços afetivos identificados na percepção dos sujeitos, desde o centro histórico de Aquiraz.

\section{Contextualização acerca do conceito de patrimônio cultural.}

A noção de patrimônio tem suas origens no império romano. O termo deriva do vocábulo latino "patrimonium", e fazia referência a "pater", que significa pai em latim, ou a "pater famílias", que significa pai de família. Dessa forma, o conceito de patrimônio, em sua origem, era algo extremamente restrito e de caráter altamente individual, pois, como nos informa Funari e Pelegrini (2009), patrimônio designava tudo aquilo que estava sob a propriedade do pai da família, do chefe da casa. Nisto incluía-se todos os bens materiais da moradia, os instrumentos de produção, os animais, os escravos e até mesmo esposa e filhos. Tudo era considerado como patrimônio e era passível de ser legado a posterioridade através da escrita de um testamento. Choay (2006) relembra o caráter familiar e jurídico do termo patrimônio, ao dizer que em sua origem, o patrimônio era ligado às estruturas familiares, econômicas e jurídicas de uma sociedade estável. A referida autora ressalta ainda que, através do tempo, outros adjetivos como natural, artístico e cultural passaram a ser atrelados a patrimônio, o que denota uma multiplicidade de significados e caminhos de análise para esse conceito. Assim, o que no início se restringia apenas aos bens pertencentes a uma família, atualmente engloba uma série de bens, tanto de natureza material (edifícios, conjuntos arquitetônicos, centros históricos), quanto de aspectos imateriais, como festividades, danças, modos de fazer etc.

As origens da noção do que hoje consideramos patrimônio cultural remonta ao século XV, em Roma, no intervalo conhecido como "Quattrocento", com o estabelecimento dos monumentos históricos. O monumento histórico, no contexto em questão, corresponderia a objetos, bens e edifícios que desempenham papel ímpar em 
duas grandes áreas do conhecimento, a história e a artes. O monumento histórico, ao mesmo tempo em que se reporta ao passado, ajuda a transmitir conhecimento do passado para as gerações futuras. Um monumento dialoga com a nossa sensibilidade artística e estética, sendo entendido também enquanto obra de arte (Choay, 2006).

Por sua vez, os séculos XIX e XX foram decisivos para a consolidação do conceito de patrimônio e para a fixação de uma legislação efetiva para a conservação e restauração destes bens, com a publicação de diversos documentos que versavam sobre a proteção destes objetos, com destaque para as Cartas de Atenas e de Venezai.

A noção contemporânea de patrimônio ganha forma a partir da década de 1980, com a introdução e popularização do termo patrimônio cultural. Até a década de 1970, o conceito de patrimônio era estritamente relacionado aos objetos e bens materiais, sejam eles monumentos, estátuas, edifícios, cidades históricas, dentre outros. Não havia sequer uma menção aos aspectos da cultura que se inserem no campo da imaterialidade. Dessa forma, festividades, danças, músicas tradicionais, a arte do saber-fazer e outros componentes importantes da cultural de uma sociedade não eram considerados tão relevantes para serem protegidos. Este cenário mudou a partir da publicação da Declaração do México, em 1985.

No escopo deste texto, delibera-se sobre temáticas e conceitos importantes, como identidade cultural, o papel da cultura no desenvolvimento das nações e sobre o patrimônio cultural. Este último foi definido da seguinte maneira:

O patrimônio cultural de um povo compreende as obras de seus artísticas, arquitetos, músicos, escritores e sábios, assim como as criações anônimas surgidas da alma popular e o conjunto de valores que dão sentido à vida. Ou seja, as obras materiais e não materiais que expressam a criatividade desse povo: a lingua, os ritos, as crenças, os lugares e monumentos históricos, a cultura, as obras de arte $e$ os arquivos e bibliotecas. (Conselho Internacional de Monumentos e Sitios [ICOMOS], 1985).

Essa nova perspectiva de olhar para o patrimônio cultural fomentou a proteção, através da inscrição nos livros de tombos, de diversos conjuntos de práticas, representações, expressões, conhecimentos e técnicas que se encontravam ameaçadas de desaparecimento por todo o mundo.

Como visto, o conceito de patrimônio cultural é fruto de um processo lento e progressivo, como nos lembra Costa (2012b), tendo como ponto inicial a ideia de monumento como objeto isolado, único e sendo a representação material do belo e da história, chegando à concepção atual, complexa, rica em possibilidades, que abrange tanto os aspectos $\mathrm{da}$ materialidade quanto aqueles que não são tangíveis, mas que permeiam a nossa esfera cultural.

É esta pluralidade que torna o estudo e o debate sobre o patrimônio tão prolífico no escopo das ciências sociais, e. sobretudo, na geografia, pois a análise geográfica desses bens culturais; dos seus processos constitutivos e da maneira pela qual são apropriados pelos sujeitos, nos auxilia na compreensão de diversos momentos da produção e valorização do espaço, da paisagem e da exploração dos territórios, que são conquistados, modificados e revalorados (Costa, 2012a).

\section{Aquiraz e o seu centro histórico.}

A cidade de Aquiraz se localiza na Região Metropolitana de Fortaleza, distando pouco mais de 30 quilômetros da capital cearense. Sua criação data do ano de 1699, quando no dia 13 de fevereiro, o rei de Portugal expediu uma ordem régia que estipulava a criação da primeira vila na, então, capitania do Ceará, com direito a eleição de câmara e juiz ordinário.

Para a recém-promovida vila, escolheu-se a alcunha de São José de Ribamar do Ceará, em homenagem a uma pequena localidade nas vizinhanças de Lisboa. Após alguns impasses e discussões, estabeleceu-se que a vila deveria ser instalada na localidade chamada de Aquiraz, pois ali se tratava de uma boa planície, com disponibilidade de água potável e de pesca, além de local adequado para o desenvolvimento de atividade portuária. Instalou-se permanentemente no ano de 1713, com a firmação do pelourinho e as construções das primeiras moradias, oficinas e a igreja matriz, que abrigaria a freguesia da capitania; a vila passava-se a se chamar de São José de Ribamar de Aquiraz, ou simplesmente, vila do Aquiraz (Oliveira, 1887).

Contudo, apesar de ser o centro administrativo e político da capitania, a vila do Aquiraz não possuía uma economia forte que viabilizasse o seu desenvolvimento. A economia era pautada, sobretudo, em uma pecuária incipiente, no comércio de cana de açúcar e seus derivados, como a rapadura e aguardente, além de farinhas, gomas, entre outros produtos. Outro fator importante para o enfraquecimento de Aquiraz no cenário da capitania do Ceará foi o surgimento e desenvolvimento de novas vilas e, 
consequentemente, a descentralização do poder econômico e político entre esses novo centros (fig. 2). Nesse período, as vilas de Fortaleza e Aracati já concentravam o comércio e as atividades portuárias, enquanto Sobral e Icó se destacavam na produção e escoamento de bens agropecuário. Assim, a influência de Aquiraz tornou-se cada vez mais restrita.

Aquiraz mergulha em profunda crise econômica durante o século XIX, visto que a vila possuía poucos atrativos que viabilizassem o desenvolvimento e seu crescimento, e não havia alternativas para mudar tal cenário crítico, pois a mesma se localizava entre duas vilas que estavam em pleno desenvolvimento, Fortaleza e Aracati. Aquiraz permaneceu enquanto vila até o primeiro quartel do século XX, quando ganhou o status de cidade em 1915. Barroso (2004) comenta que tal decisão decorreu não pelo local possuir uma estrutura condizente a uma cidade, mas como uma forma de homenagem a toda a sua história e por ter sido, sobretudo, a primeira capital da província do Ceará.
No que tange a organização espacial do centro histórico, Aquiraz possui características clássicas do urbanismo empregado nas vilas e cidades no período colonial brasileiro, mais especificamente nas surgidas durante o auge da produção açucareira (Paes, 2015). Para a autora, tais cidades possuíam uma organização bem característica, baseada em uma tríade de elementos que colaboravam para a manutenção do controle civil. Trata-se da Igreja Matriz, símbolo maior do poder religioso e do controle ideológico, a casa da câmara de vereadores, que representava o centro do poder político, administrativo e legislativo e a cadeia pública, marco do poder militar e do controle civil. Além destas, a autora menciona outras formas arquitetônicas que são bastante representativas nas povoações do período em questão, como a existência de alguns sobrados erguidos por produtores rurais mais enriquecidos, residências populares e outros prédios institucionais.

Figura 2 - Mapa de localização da vila de Aquiraz - CE em 1818

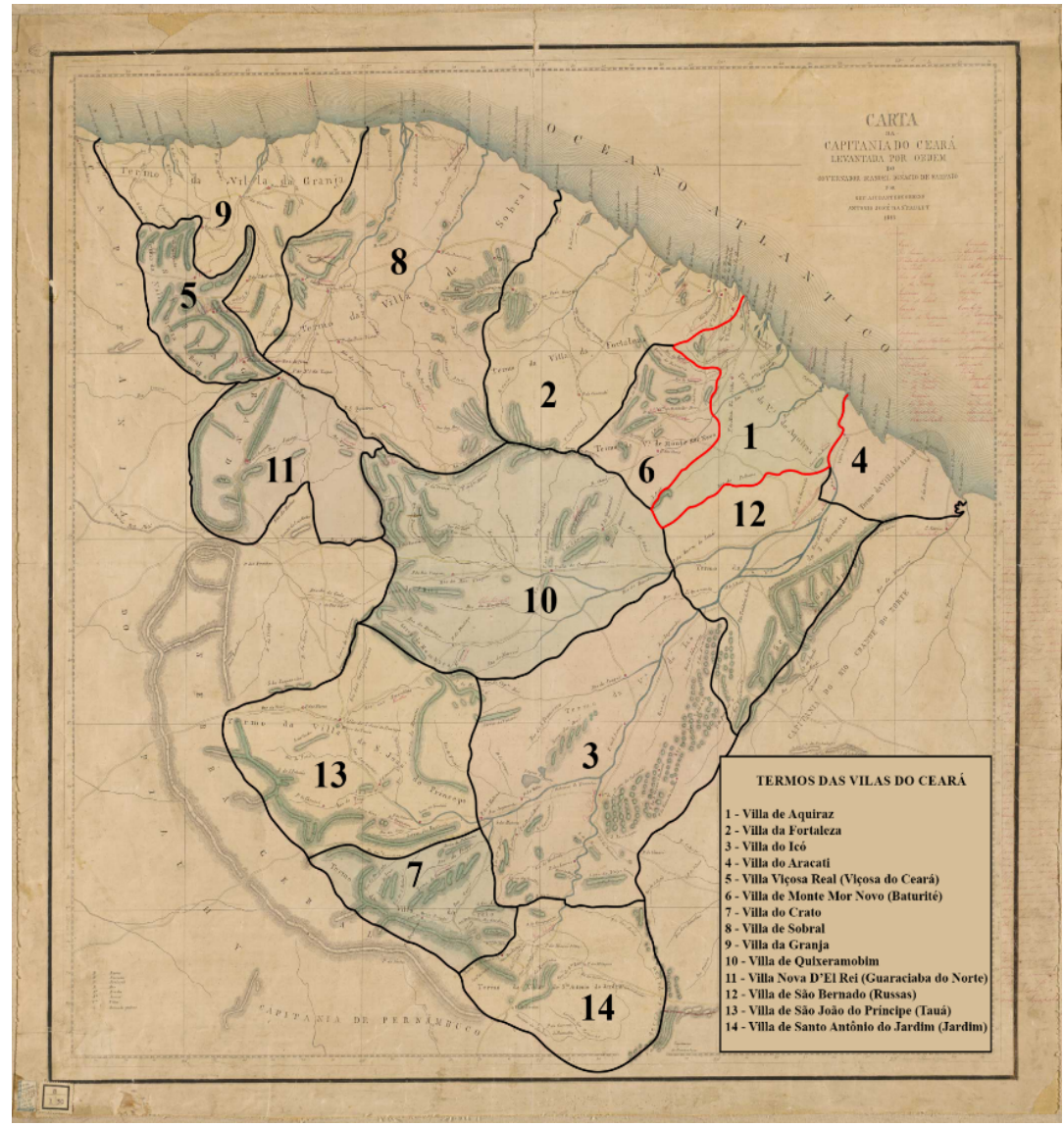

Fonte: Paulet (1818), adaptado pelo autor, 2019. 
Assim, ao observarmos a planta urbanística do núcleo histórico de Aquiraz (fig. 3) veremos que a cidade teve seu desenvolvimento partindo da Praça Cônego Araripe, também chamada de Praça da Matriz e da Igreja Matriz de São José de Ribamar. É no entorno desses elementos que se espacializam as principais formas simbólicas e bens patrimoniais da cidade, no qual destacamos o prédio da antiga Casa de Câmara e Cadeia, que atualmente abriga o Museu Sacro São José de Ribamar; a Casa do Capitão-Mor; residência tricentenária que abrigava o administrador da capitania, o Mercado da Carne, o Sítio Colégio, antiga sede de um engenho de cana de açúcar e as Ruínas dos Jesuítas.

Dos bens patrimoniais supracitados, três se destacam no imaginário afetivo popular dos moradores de Aquiraz: a Igreja Matriz, o Museu Sacro e a Casa do Capitão-Mor. Construída em 1713, a Igreja Matriz de São José de Ribamar (fig. 4) é o principal templo católico da cidade e do município. Seu estilo arquitetônico é classificado como sendo eclético, mesclando as curvas e contracurvas características do estilo barroco com as linhas retas e sóbrias do estilo neoclássico; em sua fachada, dividida em três pavimentos, destaca-se o conjunto das três portas principais, com folhas de madeira em almofadas, presentes na igreja desde sua construção; as torres são largas e quadradas, com uma janela no segundo nível e outras três no terceiro. No alto da torre da direita se encontra suspenso o sino do templo religioso (Barroso, 1999).

Por sua vez, a Casa de Câmara e Cadeia tem sua data de construção incerta, contudo, segundo informações da Secretaria de Cultura do Governo do Estado do Ceará [SECULT] (2013), sua origem é do final do século XVIII. O edifício abrigou, concomitantemente, tanto a câmara quanto a cadeia por um determinado período. Posteriormente, a câmara se transferiu para um imóvel próprio, passando a antiga Casa de Câmara e Cadeia a desempenhar somente a função de delegacia de polícia e casa de detenção.

Já em 1967, o prédio passou por uma refuncionalização e foi convertido no Museu Sacro São José de Ribamar. O equipamento cultural passou a congregar elementos religiosos oriundos de paróquias de todo o estado do Ceará, tais como imagens sacras, missais, andores, entre outros, totalizando aproximadamente 1.400 peças.

O Museu Sacro São José de Ribamar possui uma planta retangular com fundações sólidas e paredes largas.

Figura 3 - Mapa de localização das principais formas simbólicas espaciais no Centro Histórico de Aquiraz

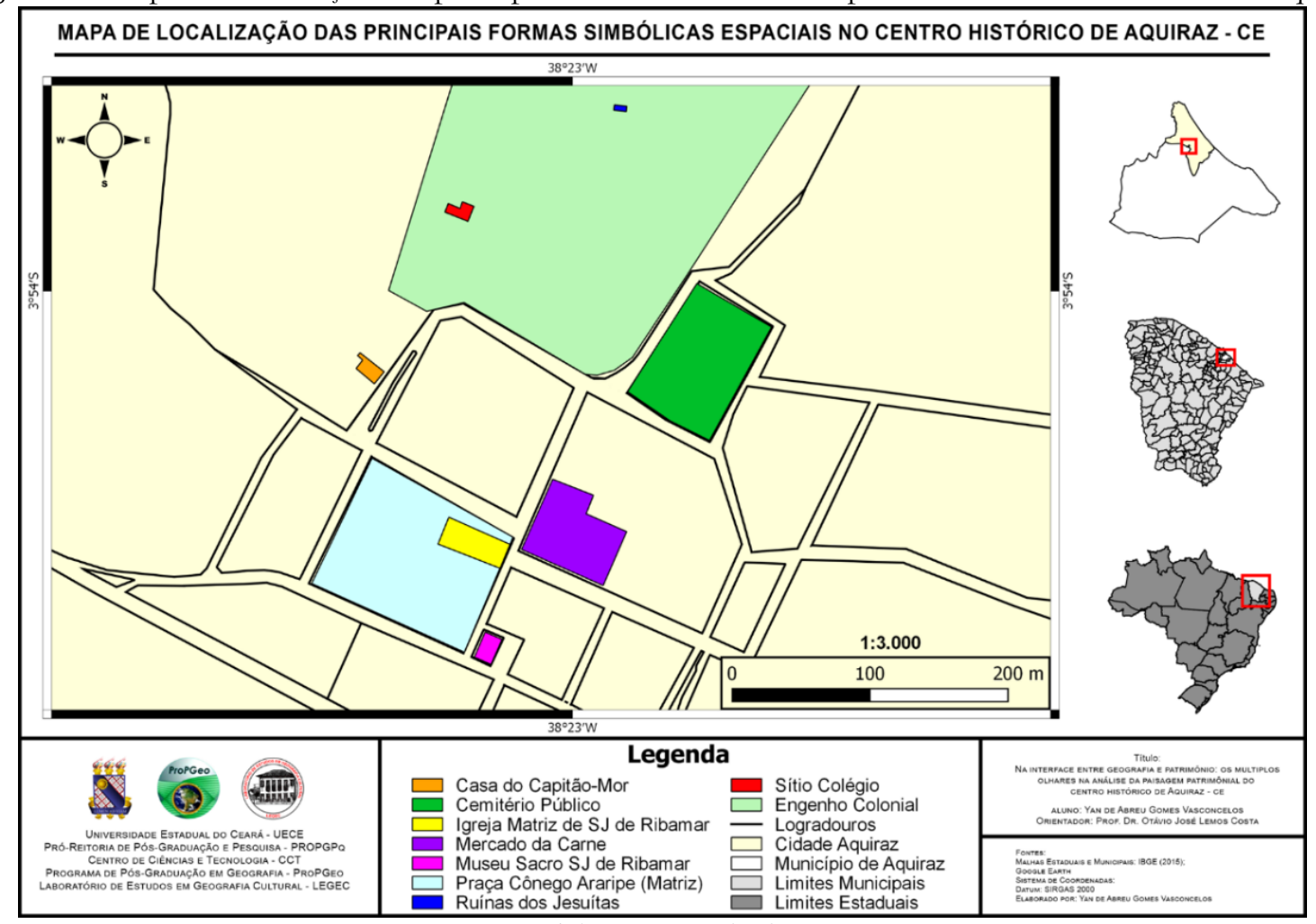

Fonte: elaboração própria, 2019. 
Figura 4 - Fachada da Igreja Matriz de São José de Ribamar

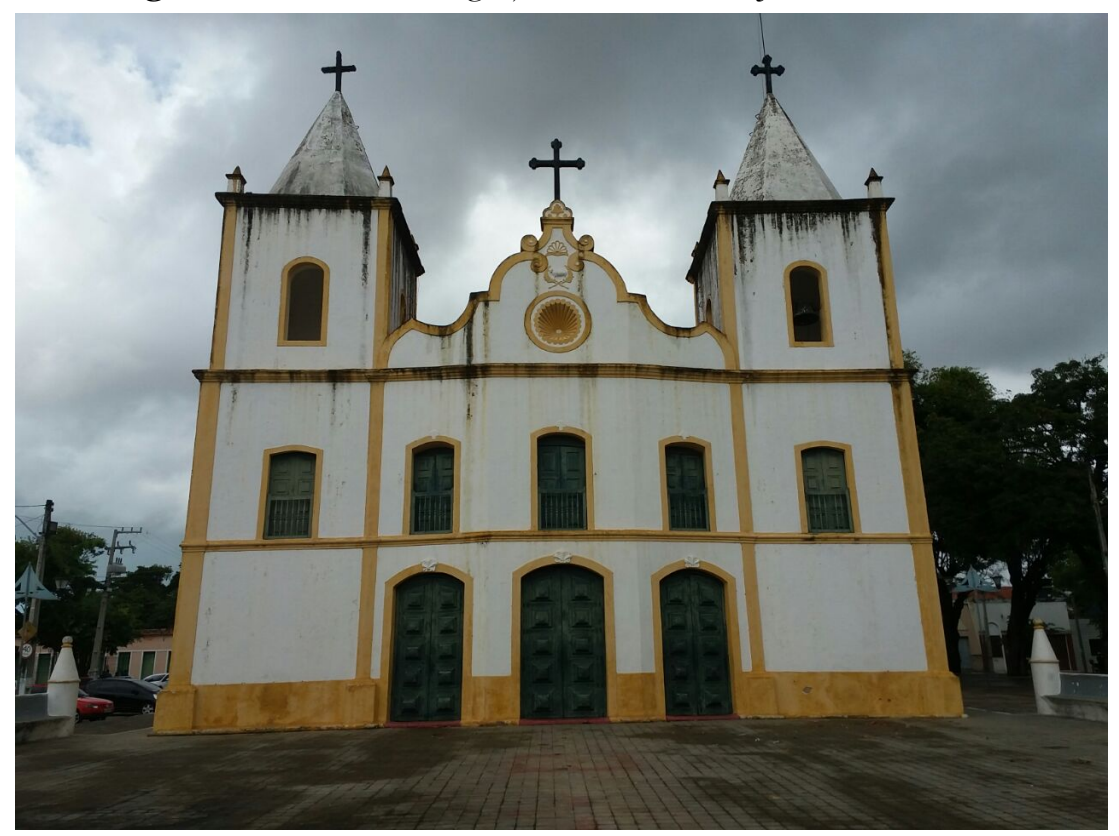

Fonte: acervo autores, 2018.

Figura 5 - Fachada da Casa de Câmara e Cadeia

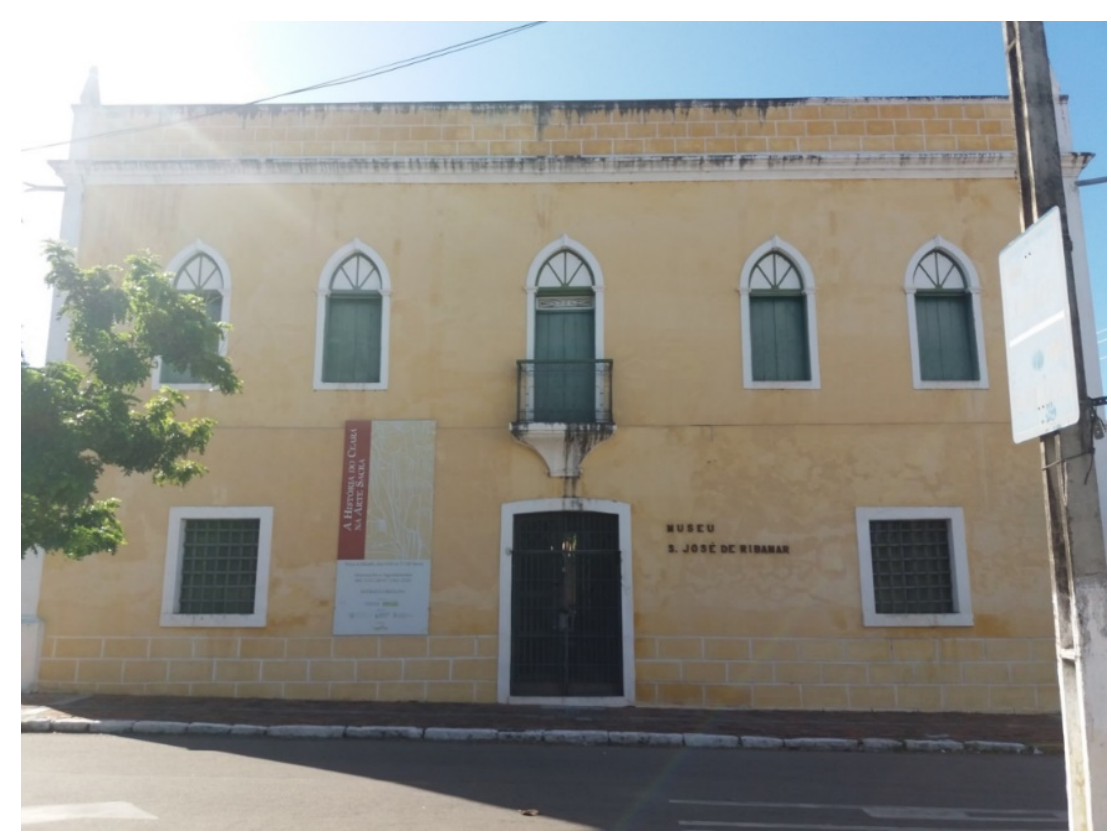

Fonte: acervo autores, 2018.

$\mathrm{Na}$ sua fachada, no pavimento inferior, destaca-se um grande portão de ferro presente na entrada, doado pelo Tesouro Provincial em 1881, além de duas grandes janelas gradeadas quadrangulares. No pavimento superior se sobressai o conjunto de quatro janelas encimadas por tímpanos ogivais, e uma porta que se abre para uma pequena varanda, ornamentada com uma grade em ferro trabalhado (fig. 5).
Por fim, a Casa do Capitão-Mor (fig. 6), construída no início do século XVIII, foi residência do Capitão-Mor Manuel da Fonseca Jaime, que governou a capitania do Ceará entre 1713 e 1716, sendo o primeiro a administrar o estado diretamente de Aquiraz. Além disso, a casa serviu de residência oficial dos ouvidores durante o período em que a vila era a cabeça da comarca. A residência, juntamente com duas construções vizinhas, forma 
um conjunto de moradias que guarda muito da memória e do modo de vida no Ceará setecentista, período no qual datam as suas edificações.

A casa possui uma planta retangular, com uma fachada simples, duas portas, uma janela e um longo alpendre sustentado por troncos de pau d'arco. Toda construída em taipa, a casa possui em seu telhado uma estrutura de madeira que utiliza troncos de pau d'arco, carnaúba e aroeira atados com tiras de couro bovino (SECULT, 2013).

No tocante ao processo de tombamento e preservação, Aquiraz não possui seu centro histórico tombado, também não há o estabelecimento de uma poligonal que delimite a área do mesmo. Assim, é compreendido popularmente como área de interesse histórico e cultural, com as edificações que se localizam no entorno da Igreja Matriz e da Praça Cônego Araripe.

Dos edifícios que ali se localizam, apenas quatro possuem proteção oficial através de órgãos de alguma das esferas públicas. A Igreja Matriz e o Museu Sacro São José de Ribamar foram elevados a categoria de monumentos do estado do Ceará em 1983, devido ao seu reconhecido valor histórico e cultural. Em 1984, o Mercado do Carne é inscrito no livro de tombos das belas artes do Instituto do Patrimônio Histórico e Artístico Nacional [IPHAN], devido a engenhosidade e precisão com a qual foi construído, numa obra que mescla a utilização de tijolos do tipo adobe e troncos de carnaúba, material bastante utilizado nas construções mais antigas da cidade. Por fim, em 2006, a Casa do Capitão-Mor é tombada pelo governo estadual devido ao seu valor histórico e arquitetônico, pois, se caracteriza como um legítimo exemplar de moradia setecentista do período colonial cearense.

Essa análise pautada em aspectos urbanísticos nos foi de suma importância para termos o entendimento acerca da morfologia do centro histórico, ou em outras palavras, para compreendermos a lógica que guiou a disposição das formas espaciais no tecido urbano do centro histórico de Aquiraz. A seguir, são apresentadas as bases teóricas que guiaram a investigação, para entendimento o processo de significação das paisagens culturais e das formas simbólicas espaciais da cidade.

Figura 6 - Fachada da Casa do Capitão-Mor

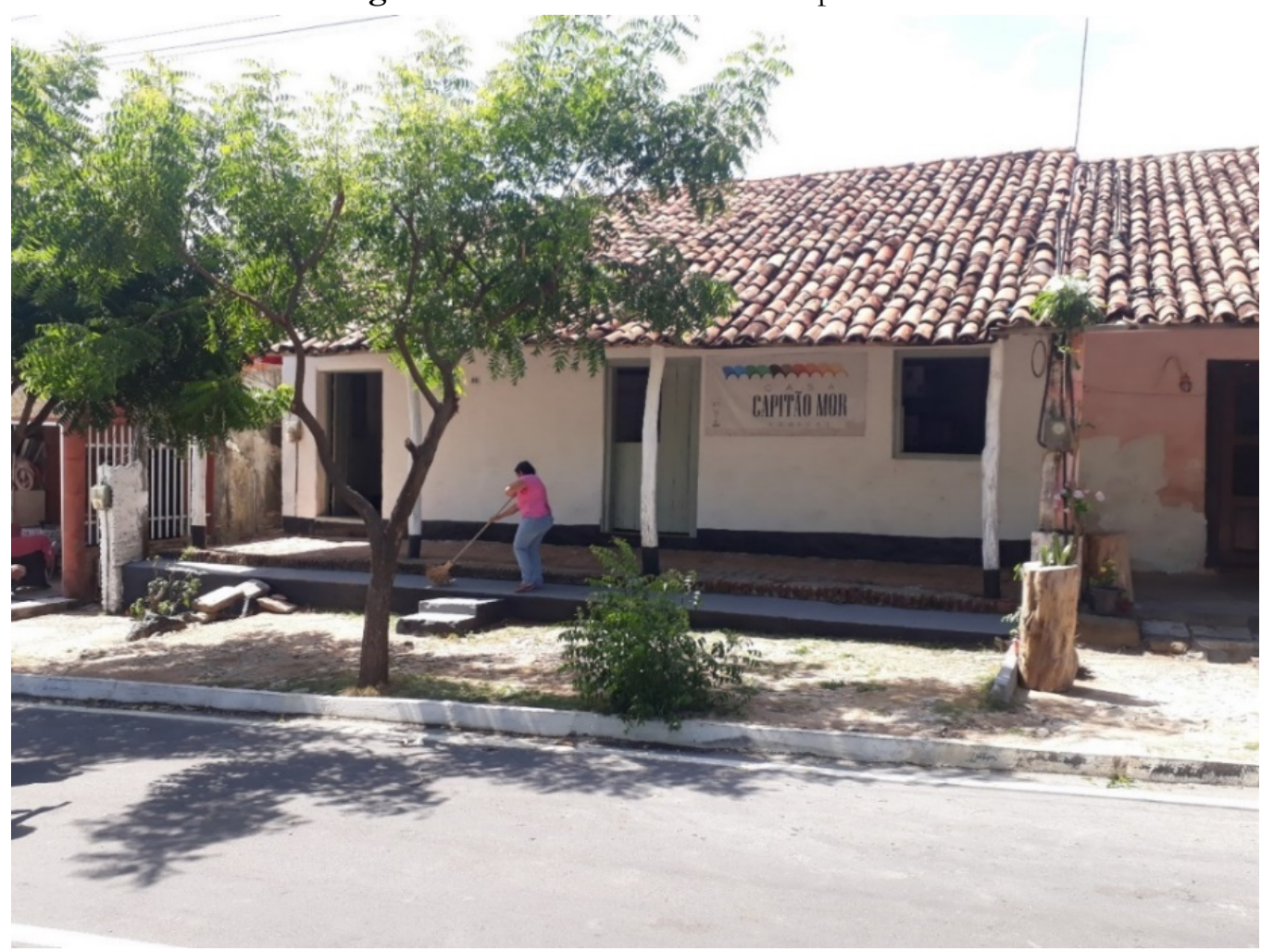

Fonte: acervo autores, 2019. 


\section{Paisagem cultural e o simbolismo.}

Como mencionado em nossa introdução, o objetivo que norteou nossa pesquisa foi a compreensão da dimensão subjetiva e simbólica que permeia a paisagem cultural do centro histórico de Aquiraz, dimensão essa que se concretiza através das relações estabelecidas entre seus moradores e as formas espaciais mais duradouras que por lá se especializam, o seu patrimônio cultural material. Entretanto, para o pleno entendimento dessa dimensão simbólica e como ela se estrutura se faz mister o discernimento do que vem a ser essa paisagem cultural.

Carl Sauer foi pioneiro ao se referir à paisagem como algo não somente natural, mas uma porção do espaço que era bastante influenciada pela presença da sociedade. Compreendia a paisagem como uma determinada parcela da superfície terrestre cujo processo de criação e modelação não advinha somente de processos físicos, de origem natural como os movimentos tectônicos ou os movimentos de massas, mas também era resultado de processos que tinham origem antrópica.

Dessa maneira, o autor concebia a paisagem como uma associação de formas distintas, tanto físicas quanto culturais; justamente na análise e observação sobre essas formas que Sauer estrutura sua linha de pesquisa. A paisagem cultural, então, seria o resultado de todas as obras realizadas pelo homem e que estão presentes para a caracterização do meio em que vive (Sauer, 2012).

Sauer (2012) propunha que a paisagem cultural era o resultado da ação modeladora de um determinado grupo cultural sobre uma determinada porção da paisagem natural. Dessa forma, a cultura era entendida como o principal agente transformador da natureza; a área natural seria o meio por onde ocorreriam as transformações, o substrato; e a paisagem cultural seria o resultado, o último estágio na cadeia evolutiva da paisagem.

O pensamento de Sauer, entretanto, não pregava uma cristalização da paisagem depois de alcançado o seu ápice de desenvolvimento. O autor entendia que a partir da ocorrência de alguma mudança no padrão cultural de determinado grupo, a paisagem passaria por um novo processo de elaboração, começando dos estágios iniciais, passando por diversas fases até alcançar seu estágio mais avançado e desenvolvido.

A partir de 1970 , a concepção acerca do conceito de paisagem cultural sofre profunda transformação. As pesquisas que antes visavam analisar somente os aspectos visíveis, as marcas materiais deixadas pelo homem na paisagem, passam também, como lembra Claval (2007), a valorizar o sentido presente nos lugares, a experiência vivida, as percepções e representações; em outras palavras, os aspectos imateriais e subjetivos que estão contidos em determinada porção do espaço.

Um dos grandes expoentes dessa geografia cultural renovada, Cosgrove (2012) entendia que a paisagem deveria ser lida enquanto uma espécie de "texto". Segundo o autor, a paisagem seria "uma maneira de ver, uma maneira de compor e harmonizar o mundo externo em uma 'cena', uma unidade visual" (Cosgrove, 2012, p. 223). Em outras palavras, a paisagem seria uma interpretação pessoal, simbólica e subjetiva baseada na percepção de cada sujeito observador da realidade que é captada pelo olhar. A paisagem seria um texto cultural cujos "vocábulos" são as formas espaciais, que estariam sujeitas a múltiplas interpretações e leituras por parte dos diferentes grupos culturais que perpassam ou vivenciam tal paisagem.

Desta maneira, Cosgrove (2012) compreende que toda e qualquer paisagem cultural é simbólica justamente por ser produto da apropriação e transformação da natureza pelo homem e ainda por ser um construto humano, servindo ao propósito de transmitir e reproduzir mensagens, normas e códigos dos grupos culturais designadamente dominantes na sociedade. $\mathrm{O}$ autor destaca que é nas paisagens mais complexas, como as cidades, os parques e as praças, que tal simbolismo é mais facilmente identificado, mas que também está presente nas paisagens mais simples como nas paisagens rurais e nos ambientes pouco humanizados.

Contextualizando as paisagens simbólicas, Cosgrove (2012) estabelece uma tipologia de análise, agrupando as paisagens em dois grandes grupos: as paisagens dominantes e as chamadas paisagens alternativas, que se subdividem em residuais, emergentes e excluídas. As paisagens da cultura dominante seriam aquelas que expressam os comportamentos, os costumes, as crenças e valores dos grupos que, de alguma maneira, exercem relações de poder e dominação sobre outros determinados grupos.

Tal influencia e domínio advém, exatamente, da eficiência que tais grupos possuem em transmitir sua visão de mundo para os demais, que a tomam como o verdadeiro reflexo da realidade (Cosgrove, 2012). O autor pontua que tais valores presentes nessas paisagens necessitam de uma constante reprodução para que não deixem de ter 
seu significado, sendo comum a realização de festividades, cerimonias e rituais públicos visando a perpetuação de certas mensagens.

As paisagens alternativas, por sua vez, são aquelas construídas pelas culturas que não possuem grande visibilidade, que são subordinadas à cultura dominante e são consideradas, muitas vezes, como subversivas e destoantes dos padrões estabelecidos. Como mencionado, podem ser divididas em três categorias: paisagens residuais; emergentes; e excluídas. As residuais são aquelas paisagens cujos elementos já não possuem muito de seus significados originais, ou, em alguns casos, já há a ausência destes. As paisagens emergentes possuem como maior característica a sua transitoriedade. São paisagens oriundas de grupos ou movimentos culturais que emergem com o objetivo de desafiar as normas e comportamentos estabelecidos pelas culturas dominantes, se fazendo presentes por um determinado período, mas que acabam por, paulatinamente, desaparecerem. Por fim, as paisagens excluídas são aquelas edificadas pelos grupos que são descartados e desprezados por grande parte da sociedade.

Trazendo essa contextualização teórica para a análise de nosso objeto empírico, vamos entender que a paisagem do centro histórico de Aquiraz se configura majoritariamente enquanto uma paisagem residual, ou então, uma paisagem-relíquia, visto que as principais formas espaciais presentes já não possuem os significados originais de quando foram idealizadas. Tomemos como um exemplo o Museu Sacro São José de Ribamar.

A edificação que atualmente abriga o equipamento cultural originalmente foi projetada para sediar a Casa de Câmara e a Cadeia Pública, símbolos máximos da regulação, do ordenamento e coerção social, ambos comandados por grupos dominantes: de um lado os políticos que formavam a esfera legislativa e do outro, a polícia. Sendo assim, tal forma espacial simbolizava as vontades e anseios de uma cultura dominante que desejava se impor a qualquer outra que desafiasse a sua supremacia. E assim permaneceu durante algumas décadas, até passarem a funcionar em edifícios próprios. A partir de 1975, a construção passa a ser sede do Museu Sacro São José de Ribamar, e o que antes significava poder, ordenamento, regulação e punição, torna-se um espaço cultural, de conhecimento e de exaltação da memória religiosa popular.

Seguindo uma linha de pensamento alinhada à de Cosgrove, Duncan (2004) vai entender a paisagem também como um texto, sendo, portanto, uma estrutura aberta a múltiplas interpretações simbólicas, variando de observador para observador. Para o autor, a paisagem é uma peça central para a concretização de um sistema cultural, pois esta corresponde a um conjunto organizado de objetos, ou formas, que atuam como um sistema de criação de signos que contribuem para a transmissão e reprodução de um determinado sistema social.

Duncan (2004) também indica duas linhas de questionamentos que guiariam o pesquisador na missão de interpretar e decodificar os múltiplos significados que permeiam as paisagens. A primeira seria investigar e ouvir os relatos daqueles que vivenciam cotidianamente determinada paisagem, a população, intentando captar as suas percepções e representações em relação ao espaço que os circunda. O autor os chama de "insiders".

A segunda linha se voltaria a analisar os discursos dos que observam a paisagem de forma "externa", os "outsiders", quais sejam: os visitantes, os turistas e a população que transita pela paisagem, mas que não possui o mesmo grau de proximidade e afeição por ela. Interpretar esses discursos permitiria extrair uma visão mais "limpa" e crítica, devido ao grau de estranhamento que o observador teria em relação à paisagem. Assim, o autor explica que "a justaposição das leituras do Outsider do "outsider" e do 'insider' pode ajudar a desfamiliarizar a relação entre paisagens, ideologias dominantes e práticas políticas ou sociais" (Duncan, 2004, p. 109).

O entendimento sobre a interpretação da dimensão simbólica da paisagem, sobretudo no que tange às análises dos relatos dos insiders e outsiders, será útil para analisar as entrevistas realizadas com os moradores de Aquiraz visando captar suas percepções acerca da paisagem patrimonial da cidade.

Assim como Duncan e Cosgrove, Meinig (2003) se cerca da dimensão simbólica que se faz existente nas paisagens, contudo, em suas análises, o autor irá concentrar seus esforços na compreensão do processo perceptivo e em como diferentes sujeitos atribuem diferentes significados a uma mesma cena ou paisagem.

Meinig (2003) explica que, ao tomar um determinado grupo de pessoas e colocá-las a observar uma especifica paisagem, cada uma irá atribuir um diferente significado àquela porção do espaço, apesar de que seus elementos constituintes (casas, estradas, montanhas, edifícios, arvores, etc.) sejam exatamente iguais.

Este fato ocorre, segundo o autor, pois o processo de significação acontece através de 
associações mentais, baseadas nos ideais, nas experiências, vivências e memórias de cada sujeito observador, e não somente através da apreensão daquilo que é concreto, que é visível. Dessa maneira, Meinig (2003, p. 35) compreende que a paisagem "é composta não apenas por aquilo que está à frente de nossos olhos, mas também por aquilo que se esconde em nossas mentes".

Em um contexto de multiplicidade simbólica, o autor elenca dez possibilidades de se olhar a paisagem do ponto de vista de seus significados, sejam eles: a paisagem enquanto natureza; habitat; artefato; sistema; problema; riqueza; ideologia; história; lugar e estética. Contudo, estes são apenas algumas perspectivas de análise da percepção da paisagem pelos diferentes observadores, havendo muitas outras maneiras de representar aquilo que é aparente em determinada porção do espaço.

Trazendo essa tipologia simbólica estabelecida pelo autor para o contexto de Aquiraz, entendemos, primeiramente, o centro histórico enquanto artefato. Para Meinig (2003), conceber a paisagem enquanto artefato é entender que tudo que se encontra sobre a superfície terrestre é fruto da ação do homem, não havendo vestígios da natureza original. Casas, ruas, edifícios, praças e até elementos que a priori seriam considerados naturais, como rios, lagos, solos e o clima, tudo é resultado da ação transformadora do homem.

O centro de Aquiraz é expressão maior do poder do homem, desde a chegada dos exploradores portugueses, em transformar a terra e lhe dar "vida", lhe proporcionar uma utilidade e uma função. A marca do colonizador está no arruamento retilíneo, característico das cidades portuguesas, em detrimento das curvas traçadas pelo relevo, na construção de uma grande praça em substituição ao largo original que era de terra batida, na construção da ponte sobre o rio Pacoti, que facilitou a entrada e saída dos moradores e visitantes da cidade na década de 1960, entre tantos outros exemplos. Pensar a cidade de Aquiraz e, mais especificamente o seu centro histórico, é perceber toda a capacidade que a sociedade possui de moldar a natureza com a finalidade de satisfazer seus anseios.

Outra possibilidade que se pode observar na paisagem patrimonial de Aquiraz é interpreta-la enquanto história. Considerar a paisagem como uma representação da história de um lugar é aceitar que ela é um profundo registro do trabalho do homem e da natureza em um determinado local. É uma acumulação e justaposição de diversas camadas temporais que ajudam a narrar o processo de desenvolvimento de uma sociedade. Neste contexto, as formas espaciais presentes na paisagem ganham notoriedade, visto que é através delas que esse relato é transmitido às próximas gerações:

A fisionomia da casa, seu tamanho, forma, material, decoração, limites, relação com outros edifícios e posição, indica-nos algo sobre o modo como as pessoas viviam ali. Ademais, cada casa teve seu construtor e em cada uma vivem indivíduos e famílias diferentes, $e$ alguma coisa disso também pode ser lido na paisagem. (Meinig, 2003, pp. 43)

Este possivelmente seja o significado mais passível de ser atribuído a um observador que se põe a olhar aquela paisagem. Aquiraz foi a primeira vila instituída na província do Ceará, e seu centro histórico, através de seu conjunto patrimonial, ajuda a descrever como era a realidade da população que vivia em uma porção do Brasil durante o período colonial. Olhar para o centro histórico de Aquiraz é ver um recorte da história, na qual cada passagem, cada acontecimento marcante está gravado nas pedras toscas das suas ruas e casas.

Um terceiro exemplo de atribuição simbólica que pode ser aplicada ao nosso objeto de estudo é interpretá-lo enquanto riqueza. Aqueles que enxergam uma determinada paisagem como riqueza tendem a "ver cada cena com os olhos de um avaliador profissional, atribuindo um valor monetário a tudo o que veem" (Meinig, 2003, p. 41). Desse modo, uma casa, um edifício ou um parque, não são apenas elementos corriqueiros na paisagem de uma cidade, mas sim componentes importantes dentro um sistema que visa sempre o acúmulo de lucro.

O centro histórico de Aquiraz entraria neste contexto, não como uma área passível de expansão imobiliária, mas como importante atrativo para atividades turísticas. Obras de requalificação de áreas históricas, reforma e restauração de conjuntos arquitetônicos, melhorias na acessibilidade e mobilidade são ações comuns nas cidades e são maneiras de transformar zonas consideradas obsoletas e degradadas em algo rentável para a administração pública. Em Aquiraz, a última grande obra de requalificação do centro histórico aconteceu no final da década de 2000, na ocasião todos os bens patrimoniais, além da praça Cônego Araripe, receberam reparos e foram revitalizados.

Devido a sua localização geográfica (fig. 3), o centro histórico funciona como um verdadeiro portal de entrada para a cidade. Com o devido cuidado, o centro histórico pode atrair muitos 
turistas, para conhecer a cultura do Ceará e do município, o que pode gerar empregos e movimentar a economia local. Este é o possível pensamento daqueles que observam aquela paisagem enquanto uma fonte de riqueza.

Contudo, a mudança de paradigmas na geografia cultural,a partir de 1970, não ocorreu apenas entre os pesquisadores anglo-saxões, como Cosgrove, Duncan e Meinig; importantes contribuições são também da escola francesa de geografia. Nesse contexto, destacaremos os pensamentos de Augustin Berque acerca da paisagem. Em seu texto "Paisagem-marca, paisagem-matriz: elementos da problemática para uma geografia cultural", o autor afirma que um dos objetivos essenciais, ou talvez o principal deles, da geografia cultural é buscar compreender o "sentido que uma sociedade dá em relação ao espaço e a natureza" (Berque, 2012, p. 239). Este sentido corresponde tanto à funcionalidade que é dada à paisagem, como à maneira que ela é pensada, construída e explorada pelos grupos sociais e aos significados que lhe são atribuídos na relação sociedade-natureza.

Assim, o autor destaca que a paisagem possui seu caráter concreto, tangível, sendo sujeita a uma análise objetiva. Acima de tudo, a paisagem é o fruto da relação que uma determinada sociedade desenvolve com a porção do espaço no qual vive, consequentemente estando envolta de intencionalidades, anseios, experiências, sendo passível também de uma análise subjetiva. A paisagem é, simultaneamente, marca e matriz de uma sociedade.

A paisagem é marca porque traduz, através de suas formas espaciais, toda a engenhosidade de uma civilização; é matriz "porque dos esquemas de percepção, de concepção e de ação - ou seja, da cultura - que canalizam, em certo sentido, a relação de uma sociedade com o espaço e com a natureza" (Berque, 2012, p. 239). Enquanto marca, a paisagem pode ser vista ou tocada, descrita e inventariada, contudo, sua análise não deve se encerrar nos aspectos tangíveis, pois, há sobre ela uma densa camada subjetiva que vai influenciar (matriz) no modo como essa realidade tangível é observada e interpretada.

Trazendo essa discussão acerca da paisagem cultural para o âmbito nacional, destacamos os pensamentos de dois pesquisadores que foram muito proveitosos para a nossa análise: Gomes (2004) e Costa (2003). Gomes (2004) compreende que as paisagens são importantes meios pelos quais uma determinada população se significa e se projeta no espaço, deixando diversas mensagens e significados codificados que podem ser assimilados por aqueles que vislumbram aquela paisagem.

Desta maneira, o autor sinaliza que a paisagem não é um elemento passivo, estático, que está à espera do momento de ser observado e interpretado pelos sujeitos observadores, mas pelo contrário, a paisagem é construída visando transmitir algo, seja uma mensagem, um significado ou uma ordem, ela está ativamente influenciando o nosso processo de significação e representação da realidade. Assim, a paisagem "objetiva nossos sentidos [...] ela funciona como uma espécie de "vitrine" de uma localidade e, portanto, de sua população" (Gomes, 2004, p. 8).

Ainda nessa perspectiva de uma paisagem ao mesmo tempo objetiva e subjetiva, Costa (2003) vai estabelecer um interessante paralelo entre o conceito de paisagem e memória. $\mathrm{O}$ autor salienta que essa associação está embasada em uma geografia da percepção, através de um conjunto de símbolos e signos que estruturam a paisagem. Tais símbolos resultam da imbricada relação entre o sujeito e o espaço que o circunda, na qual o observador vai produzir uma composição mental, subjetiva e pessoal, a partir do que é visualizado na paisagem. É com base nesses elementos simbólicos, que podem ou não terem uma realidade material, que ideais, tradições, valores, sentimentos e memórias são transmitidos no decorrer do tempo pela paisagem. É por meio dessa atividade que é construída a memória dos lugares.

Como vimos nesta contextualização conceitual, a paisagem cultural corresponde a um constructo humano que expressa toda a sua capacidade de transformação sobre o meio natural, além de exprimir, de forma material, todos os traços e vestígios deixado pelas diversas sociedades que por ali viveram. Mas, além disso, se converte em um verdadeiro campo simbólico permeado por símbolos, significados, mensagens, laços afetivos que lhe garante um caráter polissêmico em sua leitura e análise.

Contudo, nos falta ressaltar que essa dimensão simbólica se materializa no espaço através das diversas formas espaciais que se encontram distribuídas nas diversas paisagens culturais. Tais objetos por possuírem uma localização fixa e, geralmente, se perpetuarem por um longo período temporal, se inserem na vivência cotidiana dos grupos culturais e passam a pertencer aos diferentes esquemas de percepção e concepção, configurandose importantes veículos de transmissão de valores, 
crenças e significados. Estes elementos, Corrêa (2007) nomeou de formas simbólicas espaciais.

Nesse contexto de formas espaciais, Costa (2008) explica que elas podem se apresentar de maneira individual, isolada ou em arranjos sistematizados formando o espaço geográfico. Elas são as representações dos ideais, dos valores, formas de organizações sociais e memórias do passado que se materializam no espaço e na paisagem. Para Corrêa (2007), as formas simbólicas não são nada mais que interpretações de uma realidade que resultam do processo perceptivo e representativo dos mais diferentes grupos culturais. Os significados produzidos pelas formas simbólicas são reproduzidos e compartilhados entre os seus integrantes.

Corrêa (2007) explica que estas formas se tornam espaciais ao se constituírem por fixos e fluxos ou por itinerários e localizações que são atributos primordiais da espacialidade. Como objetos eivados de significados que são, as formas simbólicas necessitam estar em constante contato com o sujeito (itinerários) para assim adquirirem sua carga simbólica, logo sua localização é de extrema importância para o processo de significação. Elas necessitam, sobremaneira, de uma boa visibilidade e acessibilidade.

Elementos consagrados do patrimônio cultural material, como palácios, catedrais, estátuas e monumentos cívicos, se comportam como formas simbólicas espaciais, pois correspondem a uma obra arquitetada pelas mãos do homem, cuja função, entre outras, é a transmissão de uma mensagem. Sua preservação através de diferentes períodos históricos, portanto, garante a permanência da mensagem sempre viva na memória das novas gerações.

No entanto, apesar do patrimônio cultural, em sua expressão material, possuir esse importante valor memorial e simbólico, este não se encontra alheio ao contexto dos grandes agentes, sobretudo os do setor imobiliário, que atuam sobre a paisagem, modificando-a, como forma de obter novas formas de lucro. Esta relação patrimônio - mercado imobiliário se torna mais visível, especialmente ao olhar para as obras de requalificações dos centros históricos de cidades atrativamente turísticas.

Sobre isso, Luchiari (2005) menciona que as cidades contemporâneas, cada vez mais, acirram a competição entre si em busca da captação de capital, e que a organização e fortalecimento do setor turístico corresponde a uma das estratégias mais utilizadas nessa missão de atrair novos recursos. Nesse cenário de grande competitividade, os centros históricos das cidades tornaram-se peças fundamentais na criação desses novos polos turísticos.

A autora explica que o centro das cidades é um patrimônio que se constituiu devido ao seu papel estruturador das primeiras formas e funções urbanas durante o surgimento das cidades. Pela sua vitalidade e durabilidade, estas áreas centrais se caracterizam pela sua grande diversidade de formas e funções, atuais ou pretéritas, e pelos seus mais variados signos e significados. Contudo, apesar dessas formas antigas poderem oferecer alguma resistência, elas acabam sendo inseridas nas novas dinâmicas que implementam novos usos as paisagens, dando origem aos processos de requalificação e renovação urbana.

Sobre essas obras, Costa (2012a) informa que a requalificação urbana corresponde a uma política que se direciona ao resgate do valor simbólico das áreas urbanas, tanto como forma de beneficiar os moradores, quanto para agradar o mercado imobiliário, já as obras de renovação urbana têm o intuito de revalorizar economicamente estes lugares. Ambos os processos se inserem no movimento de estetização das cidades provocada pelo surgimento de grandes empreendimentos, públicos ou privados, que necessitam de grande aporte financeiro e implantação de novos objetos que se materializam na paisagem e permanecem após a sua realização.

Contudo, apesar dessas obras terem, em teoria, benefícios aos moradores, o que se constata na prática é que muitos desses projetos de requalificação acabam por segregar e excluir a população do acesso a essas áreas requalificadas:

Inúmeros projetos de requalificação urbana têm sido responsáveis pela expulsão das populações locais; seja diretamente, pela introdução de novos usos as edificacoones, muitas vezes seletivos e inacessiveis as populações de baixa renda; seja indiretamente, pela valorização econômica atribuida ao solo urbano, 0 que leva as populações mais pobres a venderem os seus imóveis, evitando o pagamento dos impostos que se elevam com a valorização urbana, ou mesmo buscando a obtenção de lucros e migrando para áreas periféricas menos valorizadas, o que desloca a visibilidade da segregação sócio-espacial (Luchiari, 2005, pp. 46-47).

O centro histórico de Aquiraz também se insere nesse contexto de requalificação de centros de cidades visando o incremento da atividade turística no local. A última grande obra de requalificação 
ocorreu no ano de 2010, quando foram restaurados a Praça Cônego Araripe, o Museu Sacro São José de Ribamar, o Mercado da Carne e a Casa do CapitãoMor (Governo do Estado do Ceará, 2010). Contudo, no contexto aquirazense, não foi observado uma segregação ou limitação de acesso dos moradores aos equipamentos restaurados.

\section{O percurso metodológico.}

A metodologia, no contexto dos trabalhos científicos, corresponde ao caminho percorrido no esforço de compreender a realidade ou os fenômenos estudados, aliando as concepções teóricas de sua abordagem e o conjunto de técnicas necessárias para a construção dessa realidade (Minayo, 2002). Desse modo, a escolha da metodologia é o que nos fornece as bases e ferramentas para a confirmação empírica de nossas concepções e pressupostos conceituais, construídos após a leitura de diversas teorias anteriormente constituídas.

Por nossa pesquisa se tratar de uma investigação que envolve questões subjetivas presentes em uma relação individual entre observador e objeto, na qual este o representa e lhe atribui significados embasados em suas experiências, vivências, memórias e emoções, a escolha por uma metodologia voltada a estudos de cunho qualitativo se mostrou mais viável.

A opção por uma metodologia qualitativa se justifica por esse tipo de pesquisa se voltar a questões de natureza particular, um nível de realidade que não pode ser mensurado através de dados objetivos, de equações e estatísticas. Desta maneira, ela opera no:

universo dos significados, motivos, aspirações, crenças, valores e atitudes, o que corresponde a um espaço mais profundo das relaçoes, dos processos e dos fenômenos que não podem ser reduridos à operacionalização de variáveis (Minayo, 2002, pp. 21-22).

Com isso, elegemos um conjunto que técnicas mais adequadas para o cumprimento de nosso objetivo de identificar e interpretar os múltiplos significados presentes na paisagem patrimonial do centro histórico de Aquiraz. Para a realização dos trabalhos e incursões a campo, utilizamos a técnica da observação participante, na qual o pesquisador se insere no contexto do fenômeno que investiga.
Assim, adotamos a postura de um observador participante do tipo passivo; nos inserimos no contexto da paisagem do centro histórico de Aquiraz, mas evitamos realizar grandes movimentos que causassem alguma modificação no ritmo cotidiano da população que lá reside. Somente deixamos o anonimato durante a realização das entrevistas, quando nos apresentamos e explicamos aos moradores o objetivo da pesquisa. Tal técnica somada a método de descrição densa de Geertz (2009), nos permitiu expressar a nossa visão acerca do objeto de estudo, nos fornecendo dados acerca dos costumes, das práticas sociais e culturais que permeiam a área do centro histórico.

Contudo, nossa intenção em buscar esteio nas proposições metodológicas de Geertz não foi realizar um trabalho de caráter antropológico, mas sim utilizar de algumas premissas de sua etnografia como auxilio no processo de transcrição de nossas percepções e impressões acerca da paisagem do centro histórico da cidade de Aquiraz. Assim, escolhemos sistematizar nossas ações a partir de um ato dos mais comuns em nossa rotina, o ato de se sentar em um banco da praça e visualizar o movimento da cidade.

Ao sentar no banco da Praça Cônego Araripe, ao lado da Igreja Matriz, começamos a descrever e registrar em nosso diário de campo tudo o que os nossos sentidos captavam: o movimento das pessoas; o ir e vir de seu cotidiano; seus hábitos e práticas; os sons e as cores presentes naquela paisagem; os locais onde mais permanecem os transeuntes no centro histórico; os tipos de atividades comerciais e lúdicas que existem na praça e ao seu redor; etc. Como afirma Certeau (1998), são essas práticas menores, simples, em escala microbiana, que subvertem a lógica espacial estabelecida por aqueles que dominam a cidade e verdadeiramente moldam a paisagem urbana.

No que diz respeito à leitura dos significados presentes na paisagem simbólica da nossa área de estudo, optamos pelo uso da técnica de entrevista semiestruturada. Nesta modalidade de entrevista, foi preestabelecido um itinerário de questionamentos cuja função era nos guiar para a obtenção dos melhores resultados, porém, nos reservamos a oportunidade de não nos prendermos ao plano de perguntas e pudemos realizar novas perguntas durante a entrevista.

Nosso roteiro de perguntas centrou-se em extrair dos munícipes a sua percepção do centro histórico e do patrimônio que por ali se especializa. Desta maneira, optamos por focar em perguntas relacionadas às memórias e vivências dos 
moradores, a frequência com a qual eles experimentam aquele local, e a sua opinião acerca daquele espaço urbano.

Com a intensão de preservar a identidade dos entrevistados, optamos por não divulgar os seus verdadeiros nomes no corpo de trabalho. Para a distinção das falas, optou-se pela utilização do termo "entrevistado", acrescido das iniciais dos nomes de cada um, como, por exemplo, "entrevistado ABC", "entrevistado XYZ". As entrevistas foram colhidas por intermédio de áudio-gravação como forma de facilitar o registro e transcrição das falas. As mesmas foram realizadas durante o período que engloba o segundo semestre de 2018 e o primeiro de 2019. Procuramos centrar nossas entrevistas com moradores que residem nas proximidades do centro histórico, nas ruas adjacentes à Praça da Matriz, não havendo qualquer estabelecimento de prioridades ou direcionamentos. Por fim, foram realizadas um total de dez entrevistas, com moradores de uma faixa etária que variava entre 18 e 60 anos e com as mais variadas profissões e graus de escolaridade.

\section{O centro histórico de Aquiraz: percepções e significados.}

Como mencionado anteriormente, a paisagem cultural corresponde a uma estrutura complexa que articula elementos presentes na dimensão material, através de suas formas e fluxos, bem como na dimensão do imaterial, do simbólico e do subjetivo. Dessa maneira, como nos lembra Berque (2012), é passível de uma análise formal e objetiva. Entretanto, o autor ressalta que um dos objetivos essenciais do geógrafo cultural é buscar compreender o "sentido que uma sociedade dá em relação ao espaço e a natureza” (Berque, 2012, pp. 239), sendo assim passível também de uma análise subjetiva. A paisagem, então, é, simultaneamente, marca e matriz de uma sociedade.

É neste contexto de interseção entre objetividade-subjetividade que se insere o patrimônio cultural, aqui entendido enquanto forma simbólica espacial. Costa (2012b) pontua a importância desses bens culturais para a compreensão e interpretação do processo de produção do espaço. Segundo o autor:

os bens culturais são social e historicamente produzidos e apropriados pelos homens, que lhes dão forma, conteúdo, função e sentidos diversos, de acordo com as épocas $e$ as necessidades do instante passageiro. $O$ reconhecimento das formas de apropriação dos bens culturais é fundamental para se conhecer as operações humanas sobre o meio natural, o ambiente construido e para o entendimento da organização social (Costa, 2012b, pp. 6).

Além desta relevância no movimento de compreensão da produção material do espaço, os bens culturais se convertem em formas simbólicas pois estão inseridos no processo de percepção e significação dos sujeitos que vivenciam e se apropriam do local na qual tais formas se espacializam, estando sujeitas as mais diferentes interpretações (Corrêa, 2007). É neste aspecto que nossa análise se debruçou.

Iniciamos nossos diálogos com os moradores questionando-os acerca dos seus sentimentos e sensações em relação ao centro histórico da cidade de Aquiraz. Tais questionamentos visaram nos fornecer subsídios para a compreensão sobre como tais sujeitos observadores percebiam e atribuíam significados àquela paisagem, bem como identificar possíveis laços simbólicos e afetivos entre esses habitantes e os diversos bens patrimoniais que especializam naquele local. Sentimento esse que Tuan (1980) definiu como "topofilia".

Sobre a topofilia, o autor explica que este é um neologismo que se refere a todos os laços afetivos desenvolvidos pelos seres humanos em sua vivência em um determinado local. Tais laços podem apresentar variações, de mera atração estética pela beleza de um lugar, até relações bem mais complexas e profundas, como a do sentimento de pertencimento, de lar. Esse escalamento dos laços afetivos vai estar diretamente ligado ao grau de familiaridade e proximidade que o sujeito possui com o lugar.

Assim, a percepção obtida pelo visitante ou turista é um pouco mais restrita, se limitando a um ponto de vista superficial, formado por apenas quadros de uma realidade. Sua análise é, geralmente, puramente estética. A percepção do nativo é permeada pelas suas emoções, as suas memórias e experiências. Os laços deste com o local são profundos, pois trata-se do seu lar (Tuan, 1980).

Retomando os diálogos, para o entrevistado T., o centro histórico de Aquiraz é o berço cultural da cidade: "Para mim, significa o início da cultura aqui de Aquiraz... Ou seja, em relação, a cultura significa tudo para mim" (Entrevista concedida pelo entrevistado T, em Aquiraz, Ceará, em maio de 2019). O morador ainda ressalta que a principal função do centro histórico, em sua concepção, seria 
o de veículo transmissor de valores culturais para os visitantes e turistas que viessem conhecer Aquiraz:

O papel do Centro para mim, no meu pensamento, é passar para os visitantes nossa cultura, de Aquiraz... por ter sido governo... esse é o papel principal aqui do Centro. (Entrevista concedida pelo entrevistado T, em Aquiraz, Ceará, em maio de 2019).

Entretanto, para a maioria dos entrevistados o centro histórico é muito mais do que algo relacionando à atividade turística: ele se relaciona a sentimentos mais profundos, que remetem os moradores às suas origens e ao seu passado. O centro histórico seria, para eles, um objeto de memória daquele lugar, uma espécie de marco identitário que os liga às suas raízes enquanto aquirazenses. Nesse sentido, a entrevistada V. exalta o núcleo histórico como um importante veículo de memória, de resgate ao passado.

Eu acho que é tipo um resgate do Aquirav, mesmo... da importância... Acho muito importante também eles preservarem isso... porque, justamente por isso, por você, meio que guardar uma lembrança do lugar... do início de tudo aqui. (Entrevista concedida pela entrevistada $\mathrm{V}$, em Aquiraz, Ceará, em maio de 2019).

Na concepção da entrevistada G., o centro histórico exerce uma função relevante, pois carrega um peso histórico: "é uma parte muito importante da cidade. É o coração da cidade. É a história da cidade. Eu acho muito bonito" (Entrevista concedida pela entrevistada G, em Aquiraz, Ceará, em maio de 2019).

Ainda nesse contexto de representar o centro histórico enquanto objeto de memória e culto ao passado, a entrevistada L. relata que aquele setor da cidade "é meio que uma forma de relembrar desde quando tudo começou... a história, como tudo aconteceu, essas coisas" (Entrevista concedida pela entrevistada L, em Aquiraz, Ceará, em maio de 2019).A entrevistada S. exalta o centro histórico como portador do seu passado e suas origens, mas também pontua a importância que o centro histórico desempenha para a atração de turistas e para gerar lucros para a cidade:

Pra mim, ele fala um pouco sobre o nosso passado, sobre nossa origem, de onde a gente veio... a gente tinha o Mercado da Carne que realmente trazia muitos turistas para cá, que era um meio de renda e tudo, mas ele também foi fechado, não tem mais nada lá. (Entrevista concedida pela entrevistada S, em Aquiraz, Ceará, em maio de 2019).

Já o entrevistado K. sublinha a importância da área tradicional da cidade (figura 7) para a identidade do povo aquirazense e que durante as suas aulas, tenta transmitir esse sentimento de pertencimento para os seus alunos:

Bom, o Centro Histórico de Aquiraz tem uma função muito grande, não só por mim, mas acredito mais para todos os moradores de Aquiraz, por que ele resguarda o início... Eu acredito assim... do próprio estado do Ceará e além disso, ele resguarda toda a origem e identidade do município de Aquiraz, né... Quando a gente fala em Aquiraz, a gente, com certera, já lembra do Centro Histórico, já lembra dos principais monumentos, já lembra do Museu... Por toda a sua capacidade de resguardar a bistória do município. O Centro Histórico é a identidade do município de Aquiraz, a gente tem aquele valor através das... Desde que a gente que é professor do município, a gente tenta repassar para os alunos através das aulas de campo, a gente vai no Museu Sacro... a gente vai na Igreja Matriz, a gente vai na Casa do Capitão-Mor... a gente tem como objetivo de repassar para as crianças a importância, a identidade do que é o município, e o Centro Histórico tem a capacidade de passar para as pessoas o valor de pertencimento, de lugar... Através da importância que o Centro histórico tem. (Entrevista concedida pelo entrevistado K, em Aquiraz, Ceará, em maio de 2019).

O mesmo reafirma tais valores quando comenta que a função primordial do centro histórico é preservar a história e as origens de seu povo:

É o papel de pertencimento, é o papel de saber onde a gente tá incluido, saber que a gente tem uma bistória... que o nosso município foi o berço da civilização do estado... e que ela resguarda os nossos antepassados e de tudo aquilo que já passou... é uma marca de dizer que nós tivemos uma bistória que não foi apagada. (Entrevista concedida pelo entrevistado K, em Aquiraz, Ceará, em maio de 2019). 
Figura 7 - Praça Cônego Araripe (Matriz) na atualidade

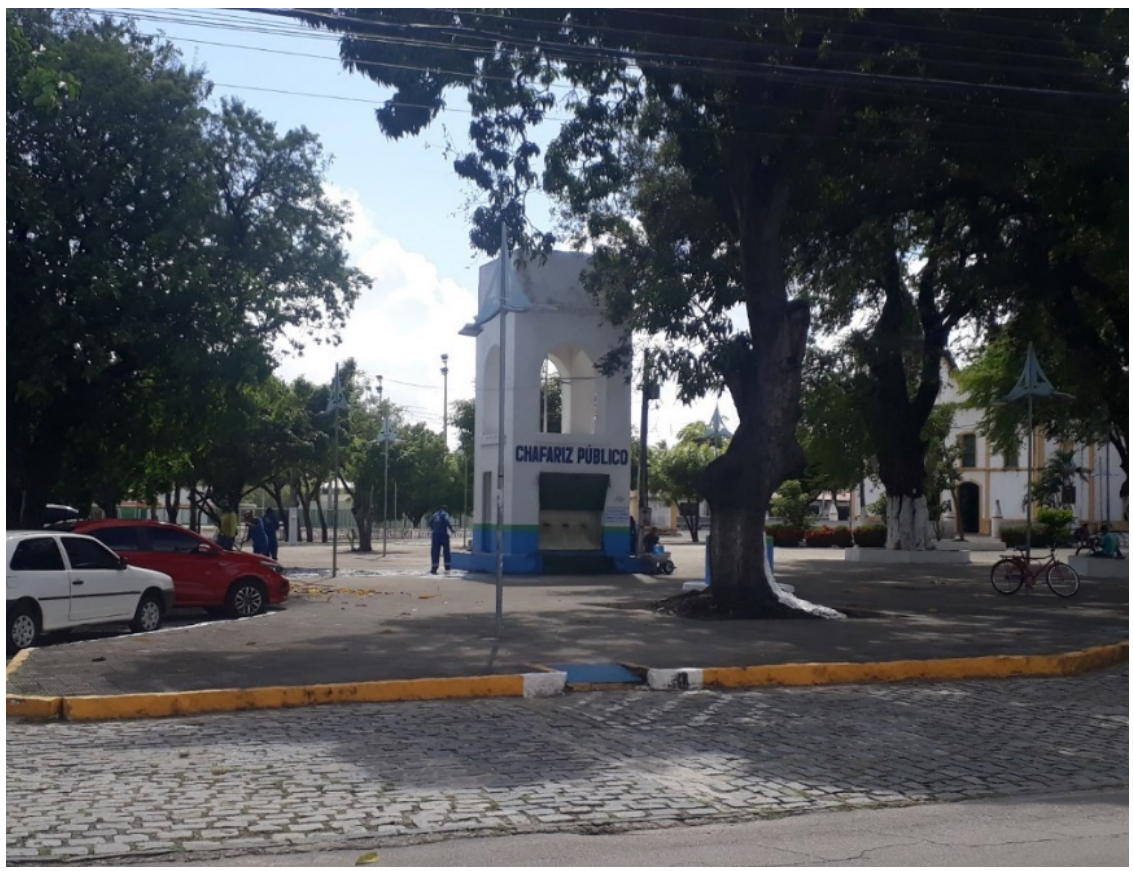

Fonte: acervo autores, 2019.

Contudo, como informa Meinig (2003), cada sujeito observa e interpreta uma mesma cena de forma diferenciada, dependendo de suas experiências, vivências e memórias. Assim sendo, houve também aqueles que apreciavam o centro histórico apenas por sua beleza estética ou o entendem como um ponto de referência do valor da cidade.

$\mathrm{Na}$ visão do entrevistado N., o centro histórico "significa uma beleza da nossa cidade" (Entrevista concedida pelo entrevistado N, em Aquiraz, Ceará, em maio de 2019). Por sua vez, o entrevistado L. representa o centro histórico como um ponto de referência do valor da cidade, de sua importância:

O centro histórico é como... um ponto de referência... um ponto que você vê o valor daquele município, o valor daquele lugar. Quanto maior, mais valor ele tem... Aqui é o valor de Aquiraz, esse centro bistórico aqui. Só que ninguém tá tendo cuidado, ninguém tá preservando, aí vai perdendo o seu valor... para mim é o valor do local, é o centro bistórico dele. (Entrevista concedida pelo entrevistado L, em Aquiraz, Ceará, em maio de 2019).

Como podemos ver através dos relatos, os moradores possuem a consciência do profundo valor histórico/memorial que se encontra velado sobre as pedras do centro histórico de sua cidade.
Existe o sentimento de que ali é o início de tudo, que aquele local é o lugar daquele povo, que suas origens e identidade estão representadas em cada uma daquelas formas simbólicas espaciais que compõem o acervo patrimonial de Aquiraz.

Dentre os nossos entrevistados, não houve depoimentos que, de alguma forma, negassem a importância do centro histórico de Aquiraz, nem que deixasse claro algum desconhecimento acerca de sua história, acreditamos que tal fato decorre do importante trabalho de educação patrimonial que é desenvolvido no município.

\section{Conclusão.}

Com a realização dos diálogos com os residentes de Aquiraz e a análise de suas falas, pudemos estabelecer uma imagem representativa, ou um quadro simbólico geral do centro histórico daquela cidade a partir de seus olhares e de suas percepções. Observamos que os aquirazenses nutrem pelo núcleo inicial de sua cidade um profundo sentimento de pertencimento e de lugar. Para eles, aquele setor da urbe representa um retorno ao seu passado, às raízes do seu povo e à sua história.

Os residentes entendem que aquele espaço simboliza o início de sua cultura e de sua identidade, um elo que os liga ao sentimento de orgulho de ser cidadão aquirazense. No que se refere ao patrimônio cultural edificado da cidade, os moradores 
compreendem que as formas simbólicas espaciais representam os marcos mais importantes da identidade aquirazense. Eles entendem tais formas como sendo verdadeiros estandartes da cultura da cidade e do município.

\section{Referências bibliográficas}

Barroso, F. (1999). Igrejas do Ceará: crônicas histórico-descritivas. Fortaleza: F.A. Barroso.

Barroso, G. (2004). À margem da História do Ceará. Fortaleza: Funcet.

Berque, A. (2012). Paisagem-marca, paisagem matriz: elementos da problemática para uma geografia cultural. In R. Corrêa \& Z. Rosendahl, Z. (Ed.). Geografia Cultural: uma antologia (pp. 239-244). Rio de Janeiro: Eduerj.

Bonnemaison, J. (2012). Viagem em torno do território. In R. Corrêa \& Z. Rosendahl (Ed.). Geografia Cultural: uma antologia (pp. 279-304). Rio de Janeiro: Eduerj.

Cardoso, A. \& Albuquerque, M. (2020). Patrimônio ferroviário e urbanizaçao em Pernambuco, Brasil. PatryTer, 3(6), 66-80. https://doi.org/10.26512/patryter.v3i6.2696 1

Certeau, M. (1998). A Invenção do Cotidiano: Artes de Fazer. Petrópolis: Editora Vozes.

Choay, F. (2006). A Alegoria do patrimônio. São Paulo: Estação Liberdade/ Editora UNESP.

Claval, P. (2007). Geografia Cultural. Florianópolis: UFSC.

Conselho Internacional de Monumentos e Sítios [ICOMOS] (1985). Declaração do México. http://portal.iphan.gov.br/uploads/ckfinder

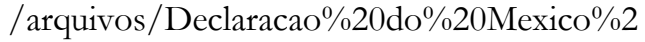
01985.pdf.

Corrêa, R. (2007). Formas simbólicas e espaço: algumas considerações. Geographia, 9(17), 718 .

https://doi.org/10.22409/GEOgraphia2007 .v9i17.a13530

Cosgrove, D. (2012). A geografia está em toda a parte: cultura e simbolismo nas paisagens humanas. In R. Corrêa \& Z. Rosendahl (Ed.). Geografia Cultural: uma antologia (pp. 219-238). Rio de Janeiro: Eduerj.
Costa, E. (2008). Refuncionalização de patrimônio cultural e a nova racionalidade da organização sócioespacial em núcleos urbanos tombados. Estudos Geográficos, 6(2), 53-73.

https://www.periodicos.rc.biblioteca.unesp. br/index.php/estgeo/article/view/496/294 2

Costa, E. (2012a). Intervenções em centros urbanos no período da globalização. Revista Cidades, 9(16), 43-58. https://revista.fct.unesp.br/index.php/revist acidades/article/view/2374/2118

Costa, E. (2012b). Patrimônio e território urbano em cartas patrimoniais do século XX. Finisterra, 93, 5-28. http://www.scielo.mec.pt/pdf/fin/n93/n93 a01.pdf

Costa, O. (2003). Memória e Paisagem: em busca do simbólico dos lugares. Espaço e Cultura, 15, 33-40.

https://doi.org/10.12957/espacoecultura.20 03.7731

Duncan, J. (2004). A paisagem como sistema de criação de signos. In R. Corrêa \& Z. Rosendahl (Ed.). Paisagem, Textos $e$ Identidades (pp. 91-132). Rio de Janeiro: Eduerj.

Espoz, M. \& Fernández, E. (2020). Políticas públicas y citybranding, valor patrimonial y turismo en la Mar de Ansenuza, Córdoba, Argentina. PatryTer, 3(6), 16-34. https://doi.org/10.26512/patryter.v3i6.2723 2

Funari, P. \& Pelegrini, S. (2009). Patrimônio histórico e Cultural. Rio de Janeiro: Jorge Zahar Ed.

Geertz, C. (2009). Uma descrição densa: por uma teoria interpretativa da cultura. In C. Geertz (Ed.), A interpretação das culturas (pp. 13-41). Rio de Janeiro: Editora Guanabara Koogan.

Gomes, P. (2004). A paisagem urbana como cenário de uma cultura: algumas observações a propósito do Canadá. Espaço e Cultura, 1718 ,

$7-15$. https://doi.org/10.12957/espacoecultura.20 04.7844 .

Governo do Estado do Ceará (2010). Governo do estado entrega patrimônio bistórico de Aquiraz. https://www.ceara.gov.br/2010/12/13/gov 
erno-do-estado-entrega-patrimonio-

historico-de-aquiraz/

Luchiari, M. (2005). Centros Históricos mercantilização e territorialidades do patrimônio cultural urbano. GEOgraphia, 14, 43-58. https://doi.org/10.22409/GEOgraphia2005 .v7i14.a13490.

Meinig, D. (2003). O olho que observa: dez versões da mesma cena. Espaço e Cultura, 16, 35-46. https://doi.org/10.12957/espacoecultura.20 02.7424 .

Mesquita, E. (2020). Território usado e lógicas patrimoniais no Paraguai. PatryTer, 3(6), 167-184.

https://doi.org/10.26512/patryter.v3i6.3228 3.

Minayo, M. (2002). Ciência, Técnica e Arte: o desafio da pesquisa social. In M. Minayo, S. Deslandes, O. Neto \& R. Gomes (Ed.). Pesquisa Social: teoria, método e criatividade (pp. 9-30). Petrópolis: Vozes.

Oliveira, J. (1887). A primeira villa da província: notas para a história do Ceará. Revista do Instituto do Ceará, 1, 103-203. https://www.institutodoceara.org.br/revista /Rev-apresentacao/RevPorAno/1887/1887APrimeiraVilladaProvincia.pdf

Oliveira, R. (2020). Patrimônio cultural, contribuição da teoria da Geografia a partir de Milton Santos. PatryTer, 3(6), 281-296. https://doi.org/10.26512/patryter.v3i6.3227 3.

Paes, T. (2015). As cidades coloniais brasileiras: Ideologias espaciais, valores histórico, urbanístico e cultural. GEOgraphia, 17(33), 41-68.

https://doi.org/10.22409/GEOgrafia2015.v 17i33.a13697.

Paulet, A. (1818). Carta da capitania do Ceará. http://objdigital.bn.br/objdigital2/acervo_d igital/div_cartografia/cart529227/cart52922 7.html.

Santos, M. (2012). A natureza do espaço: técnica e tempo, razão e emoção. São Paulo: Edusp.

Sauer, C. (2012). A morfologia da paisagem. In R. Corrêa \& Z. Rosendahl (Ed.). Geografia Cultural: uma antologia (pp. 181-218). Rio de Janeiro: Eduerj.

Secretaria de Cultura do Governo do Estado do Ceará [SECULT] (2013). Casa de Câmara e Cadeia - Museu Sacro São José do Ribamar. https://www.secult.ce.gov.br/2013/01/07/ casa-de-camara-e-cadeia-museu-sacro-saojose-do-ribamar/.

Tuan, Y. (1980). Topofilia: um estudo da percepção, atitudes e valores do meio ambiente. São Paulo: Difel.

\section{Notas}

i Foram precursoras no estabelecimento de um conjunto de diretrizes para a conservação e restauração de bens históricos. 